\title{
CD22 wt Allele
}

National Cancer Institute

\section{Source}

National Cancer Institute. CD22 wt Allele. NCI Thesaurus. Code C51116.

Human CD22 wild-type allele is located in the vicinity of $19 q 13.1$ and is approximately 18 $\mathrm{kb}$ in length. This allele, which encodes B-cell receptor CD22 protein, is involved in the regulation of $B$ cell activation sialoadhesin and in the neg ative regulation of antigen receptor signaling. 